\title{
Community Empowerment through Karya Bersama Waste Bank Program in Desa Kolam Percut Sei Tuan Deli Serdang District
}

\author{
Ibnu Hajar ${ }^{1 *}$, Marta Simbolon ${ }^{2}$, Suri Handayani ${ }^{3}$ \\ ${ }^{1,2}$ Department of Community Education, Universitas Negeri Medan, Indonesia \\ ${ }^{3)}$ Early Childhood Education Study Program, Universitas Negeri Medan, Indonesia \\ *dribnu@yahoo.co.id
}

\begin{abstract}
The aim of this study was to describe: 1) the implementation process of community empowerment through Karya Bersama waste bank program; 2) the results of community empowerment in Karya Bersama waste bank program. This study used a qualitative descriptive approach and took place in Karya Bersama Waste Bank in location of the study. The subjects were the official members and the customers of Karya Bersama Waste Bank. Data were collected with observational method, interview and documentation study. The researchers were using observation guidelines, interview guidelines and documentation guidelines. Data were analyzed using data reduction, data presentation, drawing conclusions, and verification. The triangulation used to explain the validity of data was source triangulation. The results showed that: 1) the implementation of community empowerment through Karya Bersama Waste Bank program in Desa Kolam of Percut Sei Tuan, Deli Serdang District includes three stages: awareness, ability transformation, and improved intellectual ability and skills, 2) the results of this empowerment through Karya Bersama Waste Bank program include in terms of education, economics, and health/environment.
\end{abstract}

Keywords: Empowerment, waste bank

\section{Introduction}

Nowadays, waste still becomes a problem that has not been resolved until now. Many people still consider the existence of waste as something that is not useful and even harmful. Waste is still become a classic problem for every community. In Indonesia itself, the waste problem is also a problem that is not easily solved, although the government has held various programs to overcome the waste.

Waste is closely related to public health, because from the waste will grow microorganisms that cause diseases and also insects as the carrier of disease that can infect humans. The waste problem in Indonesia is still a complex problem due to the lack of public understanding about the effects caused by these waste and the lack of government's budget to seek good and qualified disposal. Another factor that causes the waste problem in Indonesia is getting more complicated is the improvement on people standard of living that is not accompanied by the harmony of knowledge about waste and also the lack of community participation to maintain cleanliness and dispose of waste in its place [1].

Poor waste management will form a less pleasant environment for the community. For example, the unpleasant odor and a unsightly view of the environment because there is a lot of 
waste scattered everywhere. Therefore, waste becomes one of the problems that requires proper handling, because if it is not handled properly, this waste problem will become a serious problem and harm humans.

Waste management is urgently needed to overcome the plenteous waste production. Household habits in disposing waste can be categorized into two ways: disposing of waste in an environmentally friendly way and a way that is not environmentally friendly. As for what is meant by disposing of waste in a way that is not environmentally friendly, such as burying, burning, disposing to the sea / river / canal, carelessly dispose (in the field, garden, etc.).

Based on the results of the Susenas Modul Hansos, Indonesian household habits in treating waste are still not environmentally friendly. Data showed households that dispose the waste by burning ( 69.8 percent), by burying (18, 07 percent), disposed to the sea / river / canal (11.51 percent), discharged to the TPS / TPA (27.49 percent), sold or given to others (15.67 percent), turned into animal feed (10.69 percent) and recycled into compost (4.75 percent).

Indonesia is one of the countries with the largest population and has a tendency to increase from time to time. Based on the Central Statistics Agency (BPS) the population of Indonesia increased from year to year, from.281 million in 2016, then become 262.594 million in 2017, and in 2018 it increased to 266.927 million. The increasing population will result in an increase in the volume of waste generated by the community [2].

With a high population density, it will also cause employment problems. Employment is related to the level of the workforce in an area. For 2018, the total unemployment rate in North Sumatra Province is 5.59 percent or 403 thousand people. With this reality, action must be taken to reduce unemployment and poverty by creating jobs. To achieve prosperity and wellbeing in life, people must strive to obtain income that will be used to meet their needs. Factors affecting the community's economy are the amount of income, expenses, fulfillment of daily basic needs. In terms of income, poverty is described as lack of income to meet basic living needs. Reduction of unemployment can be achieved through empowerment. Empowerment is an effort to improve the dignity and levels of the society who are in a condition that unable to escape from the pitfalls of poverty and background [3].

Community empowerment can be interpreted as an effort to help the community in developing their own abilities so that they are free and able to overcome problems and make decisions independently. The purpose of community empowerment is to encourage the establishment of strengths and abilities of community institutions so that they are able to independently manage themselves based on the needs of the community itself, and are able to overcome challenges in the future [4].

Law No. 18/2008 concerning waste management and Government Regulation No. $81 / 2012$ mandate the need for a change on fundamental paradigm in waste management, which is the waste collection and transportation paradigm, that relies on waste reduction and waste management. Waste reduction activities mean that all levels of society, both government, business, and the wider community overcome the limitation of waste generation, recycling by re-use of waste or better known as Reduce, Reuse, and Recycle.

However, Reduce, Reuse and Recycle activities are still experiencing problems, that is low public awareness to sort and process waste. One solution to overcome this problem is through the development of a Waste Bank that teaches the community to sort waste and to raise public awareness in managing waste wisely and in turn will reduce the waste transported to landfill. The Waste Bank Program can be a program that can build public awareness to start sorting, recycling and utilizing waste, because waste that is utilized well has a fairly good selling value, so that the acquisition of environmentally oriented waste becomes a new culture in Indonesia. 
The development of Waste Bank in Indonesia on 2017 amounted to 5,244 Waste Banks spread in 34 Provinces or 219 districts / cities and managed waste reaching 65.8 million tons. The process in a Waste Bank is basically almost the same as other conventional banks. if in a conventional bank the community saves money and gets different money from the Waste Bank, the public only needs to save trash and will get money.

Desa Kolam is one of the villages in Percut Sei Tuan Sub-District, Deli Serdang District, which is implementing the Waste Bank program that has been started from 2017 until now which aims to address the waste problems in the village environment. Not only implementing clean and healthy life, the Waste Bank program in the village also empowers the community to start a clean and healthy life and can make money by utilizing the existing waste in their neighborhood with the motto "From waste to wages".

There are still many people who think that waste seems to be useless and has no value anymore and is considered as something that is detrimental, but actually waste still has a high economic value. For example, plastic waste is recycled into handicrafts, leaves, vegetables and fruit waste and food scraps can be recycled into compost, or into animal feed which will certainly provide benefits for people who can manage waste properly.

As a form of empowerment carried out through the Waste Bank Program in this village, it is not just exchanging waste with money alone, but the community is also given skills through training in making various types of objects by utilizing or recycling waste so that it has a beneficial economic value, for example make handicraft items such as making bags from used plastic waste, instant coffee packaging and other packages, counseling about waste segregation such as; sorting organic and inorganic waste as well as types of waste that can be exchanged at the Waste Bank and waste that can be used as handicrafts [5]. Through this program it is hoped that the community will not only think that waste is a threat, but can also be an opportunity for the community if it can be processed and utilized properly.

\section{Literature Review}

Society according to Koentjaraningrat [6] is an entity of human's life that interacts according to a particular system of customs that is continuous, and which is bound by a sense of shared identity. Continuity is an unity of community that has all four characteristics; Interaction between citizens, customs, continuity of time, strong sense of identity that binds all citizens. The concept of community empowerment includes the notion of "community based development." The main approach in the concept of empowerment is that the community is not made the object of various development projects, but is the subject of its own development efforts.

According to the Regulation of the Minister of Environment Republic of Indonesia Number 13 of 2012 Concerning Guidelines for the Implementation of Reduce, Reuse, and Recycle through Waste Banks, Article 1 states that the Waste Bank is a sorting place and collection of waste that can be recycled or reused that has economic value.

Waste Bank according to Suwerda [7] is a place where there are service activities for waste savers carried out by a Waste Bank teller. Whereas according to Unilever, the Waste Bank is a collective dry waste management system that encourages the community to play an active role in it. This system will collect, sort and distribute economic valuable waste to the market so that the community gets economic benefits from saving waste.

In general, the Bank is an agency engaged in storage, especially those related to money. But now there are banks that deal with things other than money, the Waste Bank. The Waste Bank is a foundation that was originally developed in the Yogyakarta region, and has now 
been adopted in cities throughout Indonesia. The goal, of course, is to accept the storage of waste from the surrounding community and turn the waste savings into money.

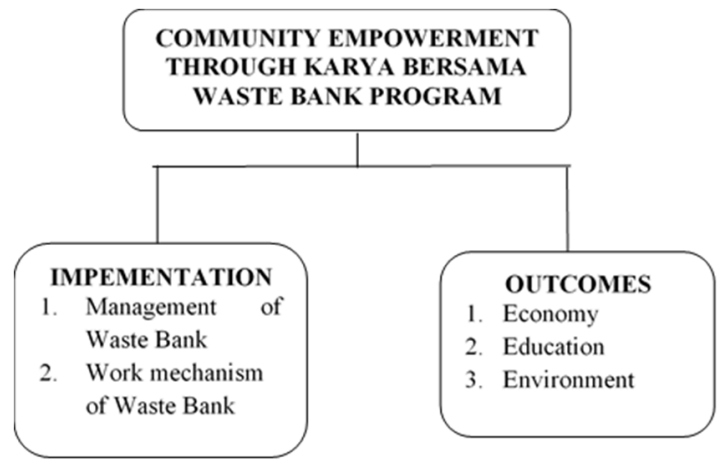

Figure 1. Framework of Thinking

Recently, waste still becomes a problem that has not been resolved until now. The existence of waste is still regarded as something that is not useful and even harmful. Poor waste management will form a less pleasant environment for the community. Waste becomes one of the problems that requires proper handling, because if it is not handled properly, this waste problem will become a serious problem and harm humans. Waste management is urgently needed to overcome the substantial waste production.

Many people still think that waste seems useless, but actually it still has a high economic value. For example, plastic waste is recycled into handicrafts, leaves, vegetables and fruit waste and food scraps can be recycled into compost, or into animal feed. One of the ways for the community to have the ability to manage waste is to empower the community itself.

Community empowerment can be interpreted as an effort to help the community in developing their own abilities so that they are free and able to overcome problems and make decisions independently. The Waste Bank is a program that teaches the community to sort waste and to raise public awareness in managing waste wisely. The Waste Bank can be a program that can build public awareness to start sorting, recycling and utilizing waste, because waste that is utilized well has a fairly good selling value, so that the acquisition of environmentally oriented waste becomes a new culture in Indonesia.

\section{Research Method}

The study used a qualitative approach and the method used is qualitative descriptive method. Through this approach the researcher is expected to be able to produce descriptive data in order to reveal the causes and processes that occur. Understanding qualitative study according to Denzin and Lincoln [8] is the study using a scientific setting and involves various methods such as interviews, observations and use of documents. The purpose of the study is to interpret the phenomena that occur. Moleong [8] defines qualitative study as a study that does not use statistical analysis procedures or other quantification methods. This qualitative study is formed with words, holistic and complicated images. This study uses a qualitative approach because it will describe the general picture of Karya Bersama Waste Bank Desa Kolam as an effort to empower the community. 
The object of this study is community empowerment through Karya Bersama Waste Bank in Desa Kolam, Percut Sei Tuan Sub-District, Deli Serdang DIstrict which includes implementation variable and outcomes. The study subjects according to Moleong are people in the background of the study. More firmly, Moloeng revealed that they were people who were used to provide information on a situation and condition in the study site.

Data collection techniques are used to discover and obtain data that meets the standards set. According to Sugiyono, more of the data collection techniques were on observation, indepth interviews, and documentation studies [10]. Data analysis in qualitative study takes place circularly and is carried out throughout the study. Since the beginning of the study, the researcher has begun to search for the meaning of the actor's behavior patterns, explanations, confirmations that may occur and record regularities.

To determine the validity (Trustworthiness) of the data required inspection techniques. The implementation of the inspection technique is based on a number of certain criteria [8]. The validity test of the data in qualitative study includes the test of credibility (internal validity), Transferability (External Validity), dependability (Reliability), and Confirmability (Objectivity). This research was conducted in May 2019 until July 2019. The location in this study was the Karya Bersama Waste Bank, Desa Kolam, Percut Sei Tuan Sub-District, Deli Serdang District.

\section{Results and Discussion}

The public's notion that said waste is useless and has no value as a resource that can be utilized, makes community participation to manage waste become minimal. Waste management which has so far been carried out by the community is still in the form of a collect-transport-dispose system, even burning and carelessly disposing it.

Starting from this, the Headman of Desa Kolam has a movement to collect waste that can be recycled for free, so the community will become enthusiastic about this movement, then the Waste Bank program is developed with the thought that if the trash is exchanged for money, more people will participate in waste management activities. The waste bank program aims to invite the people of Desa Kolam to be even more active in managing the household waste they produced. The purpose of holding this waste bank is to encourage the people to manage their waste so as to create a clean environment and to be able to utilize the waste so that it has a sale value. By creating a profit sharing system with the community that is a customer, it is hoped that it can increase the people's income and encourage the community to be more active in managing waste.

\subsection{Implementation of Community Empowerment through Collaborative Waste Bank}

The community still sees waste as useless and gives no value. This makes the community participation in waste management become minimal. One of the innovations made to change the community to be more concerned about waste is the implementation of a waste bank. Karya Bersama Waste Bank was officially established in 2013. The waste bank program aims to encourage the people in Desa Kolam to be more active in managing the waste they produced in their respective households. The waste bank program is an activity to teach the people to manage waste properly so that they care about the environment because the intensity of burning and illegal disposal of waste is reduced and can increase family income from waste savings, compost sales and waste recycling crafts. 
Waste bank is one of the strategies to implement Reduce, Reuse, Recycle (3R) in managing waste at its source at the community level. The waste management system with waste savings involves the participation of the community to manage waste together. In the waste bank activities contained efforts to make people independent to reduce the waste they produced, utilize and recycle waste.

The waste bank program is inseparable from community empowerment. Community empowerment, according to Sunyoto Usman [11] is a process in the framework of efforts to strengthen independence. Empowerment is an effort to improve people's lives by providing an understanding of control about social, economic, and political forces. Community empowerment is not forever, in other words community empowerment takes place through a learning process that is carried out in stages to achieve independence. The process in the context of community empowerment will take place in stages. According to Hempri \& Suparjan [12], in the context of community empowerment there are several things that need to be conducted, including:

a. Increase the critical awareness or position of the community in the socio-political structure;

b. Critical awareness that arises is expected to make the community able to make arguments for various kinds of exploitation and at the same time make a decision on it;

c. Community capacity building;

d. Empowerment also needs to be interconnected with the social and cultural development of the community.

The main thing that is most important in the context of community empowerment is to increase critical awareness or the position of the community. At this stage, an trainer or person who gives direction will make the community aware of their existence as individuals and as members of the community so that they can be independent with an effective empowerment process. Awareness can show the current condition of society and show the importance of change to improve the situation. So that it can stimulate the mindset of people to improve conditions so that a better future can be achieved. The awareness phase carried out by the management of Karya Bersama Waste Bank were about the importance of managing household waste and the impact of the household waste produced by residents if it was not managed properly. The awareness phase of the Desa Kolam residents is carried out through the socialization of waste savings and donation, counseling on environmental cleanliness, and training in making handicrafts from waste, and training on processing organic waste into compost fertilizer.

In principle, the implementation of a waste bank is one of social engineering to encourage the community to sort waste. Through the waste bank, an innovative solution was found to advance the community in selecting waste. By equating waste with money or valuable things that can be saved, the community is finally educated to recognize waste according to the type and its value so that they are willing to sort the waste [13]

With the increasing public awareness about the importance of maintaining environmental hygiene has made the management of Karya Bersama Waste Bank got the idea to process and recycle waste into something valuable. The awareness process about the importance of waste management is carried out by means of socialization activities by the Karya Bersama waste bank management. This is also in accordance with previous study conducted by Bambang Suwerda [7] the method taken in raising awareness of the community is by socialization activities and invitations to save waste, while also using brochures and installing leaflets in strategic places. 
Socialization activities and introduction of independent waste management to the community are carried out by socialization and counseling in the associations that exist in Desa Kolam. In each of these meeting, the community is invited to manage waste properly and to reduce plastic waste as much as possible.

After public critical awareness arises, it is hoped that the community will be able to make decisions to participate and play an active role in empowerment carried out by the Karya Bersama waste bank through various work programs. Karya Bersama waste bank managers socialize the Karya Bersama waste bank work program in the form of waste saving activities aimed at making the community able to participate in waste management activities and instilling the importance of public awareness in maintaining environmental cleanliness. The form of independence or assistance that is carried out by the management of the Karya Bersama Waste Bank to the public and customers in the form of training on waste management and sorting the waste that can be recycled that and training to make compost with the composters in several places in the Desa Kolam and always invite the residents to always protect the environment in order to stay pleasing. Based on observations made by researchers in Desa Kolam, it shows that in social activities such as social gathering, surveying and other Desa Kolam residents' activities, the management of Karya Bersama waste bank always take the time to provide socialization about the Karya Bersama waste bank program and invite the residents to participate in activities held by the Karya Bersama waste bank management.

The direction of community independence in the community empowerment program is in the form of assistance to prepare the community to be able to manage their own activities. The self-reliance activities are carried out continuously by the management of Karya Bersama Waste Bank, so that the Waste Bank program can be executed in accordance with the established procedures and objectives. The form of independence executed by the management of the Karya Bersama waste bank is by continually reminding and motivating the community to independently manage the waste they produce in their homes, where the community must sort waste from the household level. The goal to be achieved in an empowerment according to Ambar Teguh (2010: 80) is to shape individuals and communities to become independent. Assistance for residents who manage waste is carried out by management with house-to-house socialization which is divided into teams. The independence of the community in managing waste can be seen from the initiative and public awareness to manage waste by sorting and combining the waste they produce with the Waste Bank.

The results of the study show that community empowerment carried out through Karya Bersama Waste Bank has had a positive impact on the community so that they can manage their waste independently and have additional income from waste savings and handicrafts made from waste

\subsection{The Outcome of Community Empowerment Through the Management of Collaborative Waste Bank}

A program that has already implemented will provide diverse outcomes for a person or group, especially if the programs implemented in the community are the main targets in determining the sustainability of the program going forward. With community empowerment, it will bring income to the community [13].

The outcomes of empowerment are generally centered on economics because the main goal is to empower the community, where the economic role is very important. However, a qualified human development not only involves economic aspects, but also other aspects, including education, health, spiritual and culture [14]. 
The implementation of community empowerment through the Karya Bersama Waste Bank has an impact on the Desa Kolam residents especially those who are the customers. The outcomes of waste management at the waste bank for the community can be seen from three aspects, including education, health and socio-economics where the community gets knowledge from sorting out waste, cleanliness and environmental health around their homes and increasing people's income from saving waste and establishing a good relationship among community members. Based on the results of the study, it is known that the outcomes of community empowerment through the Karya Bersama Waste Bank can be reviewed in terms of economic, health or environmental and social aspects.

a. Economic aspects

In the economic aspect, the waste collection activity at Karya Bersama Waste Bank provides benefits in the form of additional income for families, especially families who are customers because the money from the savings can be used to increase family expense. In addition to increasing family expense, the outcomes of saving at a waste bank can be an additional fund for people who have their own businesses at home.

b. Educational Aspects

In the aspect of education, the community that has become a customer has chosen organic and inorganic waste. Where inorganic waste still has to be sorted again to be grouped according to its type. The community is given three sacks to classify the waste collected by the community. With a sorting system like this, there is an effort to educate citizens to sort out inorganic waste and they become more concerned about the environment. The community has learned how to manage waste properly and correctly. For customers who participate in waste recycling training, they will have additional knowledge from the training they have received, so the waste that was originally not valuable can be changed into something that has aesthetic value.

c. Health or Environmental Aspects

In the aspect of health or the environment, waste management activities with the waste savings system carried out by the Karya Bersama Waste Bank also provide benefits in terms of health. With waste collection activities, it can create a cleaner environment, healthier and free from waste, and also the waste scattered around the residence will decrease. As in the canals usually had a lot of plastic waste but now is increasingly reduced because the waste they produce has been collected for savings at the waste bank. The residents experienced a good change in treating waste and getting benefits from good waste management.

\section{Conclusion}

Based on the results and the discussion of this study, it can be concluded several things as follows: Implementation of community empowerment through the Karya Bersama Waste Bank includes three stages: a) Socialization b) Implementation of Waste Savings Services c) Waste Recycling Training d) Monitoring and Evaluation e) Mentoring The implementation of community empowerment through Karya Bersama Waste Bank program provides outcomes for the community, in terms of education, environment / health, economic and social. In terms of education, the effort to educate citizens to sort the waste and they become more concerned about the environment and understand how to manage waste properly and correctly. In the aspect of health or the environment, with waste collection activities, the environment around 
the residents's homes can be cleaner, healthier and free from waste. In terms of economics, waste collection activities in Karya Bersama Waste Bank are providing additional income. In the social aspect, waste collection activities in Karya Bersama Waste Bank provides benefits to the management and customers so that they often meet with each other and interact with each other, so that there is a good relationship between community members. Culturally, the habits of the community who dispose of waste without being sorted and consider waste as an item that has no value has changed, the community has realized the importance of environmental health and the importance of managing waste.

\section{Recommendation}

Based on the results of this study several recommendations could be made as follows:

1) The management must further create independence in the community, the community must be independent to be able to sort and deliver the waste, so the management does not need to pick up the waste to the customers' homes.

2) Assistance to the community should be improved since not every customers are active in waste collection activities in Karya Bersama Waste Bank.

3) For the management, it is better to market the results from community crafts through social media and so forth.

\section{4) References}

[1] Ahmad, Sururi. (2015), Pemberdayaan Masyarakat Melalui Program Pembangunan Insfrastruktur Perdesaan dalam Meningkatkan Kesejahteraan Masyarakat Kecamatan Wanasalam Kabupaten Lebak. Jurnal Administrasi Negara, 3 (2), pp.1-25.

[2] Mardikanto, T \& Soebiato, P. (2015), Pemberdayaan Masyarakat dalam PrespektifKebijakan Publik. Bandung: Alfabeta.

[3] Noor, Munawar. (2011), Pemberdayaan Masyarakat. Jurnal Ilmiah CIVIS, I (2).

[4] Sumartiningsih, Fr. M. S. (2004), Pengaruh Kompetensi profesianal dan Iklim Organisasi terhadap kinerja Dosen (Studi Kasus pada Akademi Keperawatan Budi Luhur dan Achmad Yani Cimahi). Tesis. Program Pasca sarjana - UPI.

[5] Wijaya, I.K. (2016), Pemberdayaan Perempuan Melalui Pelatihan Kerajinan Oleh Kelompok Azalea di Bank Sampah Gowok Kelurahan Catur Tunggal Depok Sleman. Universitas Negeri Yogyakarta, Yogyakarta.

[6] Koentjaraningrat. (2009), Pengantar Ilmu Antropologi. Jakarta: PT. Rineka Cipta.

[7] Suwerda, B. (2012), Bank Sampah Kajian Teori dan Penerapannya. Yogyakarta: Rihama-Rohima.

[8] Moleong, Lexy J. (2012), Metodologi Penelitian Kualitatif. Bandung: Remaja Rosdakarya.

[9] Uthami, Agnes. (2016), Implementasi Program Pemberdayaan Masyarakat Terhadap Pengelolaan Sarana Air Bersih Berbasis Masyarakat. Universitas Bandar Lampung, Bandar Lampung.

[10] Sugiyono. (2014), Memahami Penelitian Kualitatif. Bandung: Alfabeta 
[11] Usman, Sunyoto. (2008), Pembangunan dan Pemberdayaan Masyarakat. Yogyakarta : Pustaka Pelajar.

[12] Suparjan dan Hempri Suyatna. (2003), Pengembangan Masyarakat Dari Pembangunan Sampai Pemberdayaan, Yogyakartam Pustaka Pelajar.

[13] Kementerian Lingkungan Hidup RI. (2012). Bank Sampah dan 3R: Membangun Lingkungan dan Ekonomi Kerakyatan.

[14] Totok Mardikanto dan Poerwoko Soebianto. (2012), Pemberdayaan Masyarakat dalam Perspektif Kebijakan Publik. Bandung: Alfabeta. 